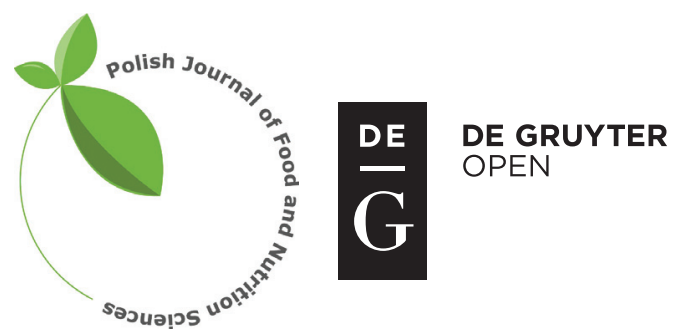

Pol. J. Food Nutr. Sci., 2018, Vol. 68, No. 4, pp. 319-325

DOI: $10.2478 /$ pjfns-2018-0001 http://journal.pan.olsztyn.pl

Original research article

Section: Food Quality and Functionality

\title{
Impact of Cooking Temperature on In Vitro Starch Digestibility of Rice Varieties with Different Amylose Contents
}

\author{
Sofía Guillén, Rosa Oria, María Luisa Salvador* \\ Plant Foods Research Group, Instituto Agroalimentario de Aragón - IA2 - (Universidad de Zaragoza - CITA), \\ Miguel Servet 177, 50013 Zaragoza, Spain
}

Key words: glycemic response, resistant starch, rice, slowly digestible starch

The aim of this study was to evaluate the effect of cooking temperature on the in vitro starch digestibility of four varieties of rice: Basmati, Calrose, Arborio and Bomba. Total starch, resistant starch and amylose contents were determined in raw and cooked samples. The in vitro kinetics of starch hydrolysis were also determined, and the hydrolysis and glycemic indexes were estimated. Both the initial amylose content and the cooking temperature had a significant influence on the resistant starch content. Rice cooked at $95^{\circ} \mathrm{C}$ retained a higher resistant starch content than rice cooked at $100^{\circ} \mathrm{C}$. The in vitro study of starch hydrolysis showed that hydrolysis tended to be slower and less complete for rice with a higher amylose content and for rice cooked at a lower temperature. Cooking rice at $95^{\circ} \mathrm{C}$ instead of $100^{\circ} \mathrm{C}$ reduced the estimated glycemic index by approximately $10 \%$ for the varieties tested.

\section{INTRODUCTION}

The variable formation of resistant starch is one of the factors that influences the rate and extent of digestibility of starchrich foods, such as rice. The implications relate to the glycemic response, the level of postprandial glucose and the insulin response, and diseases such as diabetes or obesity [Champ et al., 2003]. The glycemic index of rice is relatively high compared to those of other starchy foods and depends on factors such as variety, amylose content and processing [Hu et al., 2004; Kaur et al., 2016]. Rice varieties with high amylose contents have a lower glycemic response because the starch is not completely gelatinized under normal cooking conditions; this generates a higher resistant starch content [Trinidad et al., 2013]. The amylose content of the rice variety has also culinary implications because it has an influence on the organoleptic qualities of rice once cooked [Li et al., 2016]. Rice with a higher amylose content has a higher gelatinization temperature and a higher starch retrogradation enthalpy [Varavinit et al., 2003; Zhu et al., 2011], resulting in a harder texture after the cooking process [Yu et al., 2009]. The hardness of cooked rice is associated with amylose retrogradation. The impact of different cooking methods on starch digestibility has been previously analyzed [Sagum \& Arcot, 2000; Han et al., 2008; Reed et al., 2013]. In these studies, rice was cooked in different appliances in order to evaluate the effect of different factors on starch hydrolysis such as the heating

\footnotetext{
* Corresponding Author: Tel: +34976762739;

E-mail: mlsalva@unizar.es (Maria L. Salvador)
}

process, the presence of oil or cold storage. However, no studies have been found that take into account the influence of cooking conditions (temperature / time) on the formation of resistant starch or the glycemic index. The objective of this work is to evaluate the influence of cooking conditions on the digestibility and glycemic index of four varieties of rice with different amylose contents. The appearance on the market of new induction plates equipped with temperature control systems allows cooking below atmospheric boiling temperature in a domestic environment. Therefore, it was investigated whether cooking rice at a temperature below $100^{\circ} \mathrm{C}$ may have an influence on the resistant starch content and the glycemic index of cooked rice.

\section{MATERIALS AND METHODS}

\section{Materials}

The rice samples used were Basmati, Calrose, Arborio, and Bomba (Nomen, Arrosaires del Delta de L'Ébre, Tarragona, Spain). The selection of the rice varieties was based on amylose content. Basmati is an Indica-type long-grain variety with a high content of amylose $(\sim 22 \%)$ that is cultivated mainly in India and Pakistan. Calrose, Arborio, and Bomba are short-grain varieties (Japonica type) with a lower content of amylose (15-11\%).

\section{Cooking conditions}

All the samples were cooked using a PIB.67L34E induction hob (Bosch, Germany) equipped with a temperature control system and an 18-cm-diameter Bra Terminox pot (Sant 
Boi de Llobregat, Barcelona, Spain) made of 18/10 stainless steel with a capacity of $1.75 \mathrm{~L}$. One hundred grams of raw rice were cooked without a lid in $0.8 \mathrm{~L}$ of tap water. After cooking, the rice was drained for $1 \mathrm{~min}$. The cooking time for each variety at 95 and $100^{\circ} \mathrm{C}$ was determined by removing ten kernels every minute during cooking and pressing them against a black background using a glass plate until no white core was left [Zhang et al., 2015]. Three batches were made for each of the experimental conditions.

\section{Sensory evaluation}

The sensorial tests were carried out by ten trained panelists in a normalized sensory room following the spectrum descriptive analysis method [Meilgaard et al., 2006]. The descriptive analysis of the cooked rice consisted of five sensorial attributes for each sample: adhesion to lips, hardness at first bite, cohesiveness of mass after three chews, toothpull and toothpack after mastication. The definitions of these attributes and the techniques to evaluate them were those described by Miao et al. [2016]. Samples were presented at $70 \pm 2^{\circ} \mathrm{C}$ in preheated glass bowls insulated with extruded polystyrene foam covered with watch glasses. Samples were served one at a time in randomized order to the panelists, who sat in individual booths under a red lighting system. The panelists evaluated the samples using an intensity scale ranging from 0 (not perceived) to 10 (very intense). References were provided to the panelists to use as anchors for specific attributes [Meullenet et al., 1998]. The samples were tested in duplicate; therefore, eight samples were evaluated in the testing session.

\section{Texture analysis}

Following the method used by Yu et al. [2009], a textural profile analysis (TPA) of the cooked rice was conducted. Tests were performed using a TA-XT Plus Texturometer (Stable Micro System, Godalming, United Kingdom) equipped with a $50 \mathrm{~kg}$ load cell. Three grains of cooked rice, equilibrated to room temperature, were twice compressed to $90 \%$ of the original thickness using a $\mathrm{P} / 20$ cylindrical probe. The pre-test speed was $1.0 \mathrm{~mm} / \mathrm{s}$, while the test speed and post-test speed was $0.5 \mathrm{~mm} / \mathrm{s}$. The values of hardness, cohesiveness and adhesiveness were obtained from the aforementioned TPA curves. Thirty replicates (ten from each bath) were evaluated from each condition, and the results were presented as the mean values.

\section{Amylose content}

Determination of the amylose content of the rice samples was carried out using an amylose/amylopectin assay kit (KAMYL 09/14, Megazyme International, Ireland) according to a procedure based on the method of Yun \& Matheson [1990]. Samples were freeze-dried and then ground. Next, they were dissolved in dimethyl sulfoxide and then precipitated with ethanol. Lipids remaining in the supernatant were discarded. After the dissolution of the precipitated sample in a solution of acetate/salt, amylopectin was specifically precipitated by the addition of concanavalin A and removed by centrifugation. The amylose was hydrolyzed to D-glucose with a mixture of amyloglucosidase/ $\alpha$-amylase enzymes.
Subsequently, GOPOD reagent (containing glucose oxidase/ peroxidase enzyme) was added, resulting in a colorimetric reaction. An aliquot of the acetate/salt solution was separated and its total starch was also hydrolyzed to D-glucose. The absorbance of each sample was read at $510 \mathrm{~nm}$, and the concentration of amylose was calculated as the quotient between the absorbance of the supernatant and that of the total starch sample. Six replicates (two from each bath) were evaluated from each condition, and the results were presented as the mean values.

\section{Resistant starch (RS), digestible starch (DS) and total starch (TS)}

Resistant starch (RS), digestible starch (DS) and total starch (TS) contents were determined using an assay kit (KRSTAR 05/2008, Megazime International, Ireland) according to a method accepted by the AOAC [1990] (Official Method 2002.02) and AACC [2000] (Method 32-40) associations. The ground sample was incubated at $37^{\circ} \mathrm{C}$ for exactly $16 \mathrm{~h}$ with porcine pancreatic $\alpha$-amylase and amyloglucosidase (AMG) with the addition of maleate buffer. The reaction was terminated by the addition of ethanol and the RS was recovered as a pellet by centrifugation. This was then washed twice in ethanol. Then, $\mathrm{KOH}$ was added to the pellet, and the RS was dissolved by stirring in an ice-water. The solution was neutralized $(\mathrm{pH} 3.8)$, and the starch was quantitatively hydrolyzed to glucose with $\mathrm{AMG}$ at $50^{\circ} \mathrm{C}$ for $30 \mathrm{~min}$. D-Glucose was measured with GOPOD, which was a measure of the RS of the sample. Digestible starch (DS) content was determined by pooling the original supernatant and the washings and measuring D-glucose content with GOPOD. The total starch content was calculated as the sum of resistant and digestible starch. Six replicates (two from each bath) were evaluated from each condition. To express the different starch contents in a dry matter (DM) basis, the moisture content of the grains was calculated using the standard $\mathrm{AOAC}$ method [1990] by weight loss after drying at $105^{\circ} \mathrm{C}$ for $24 \mathrm{~h}$ in a forced convection oven.

\section{In vitro kinetics of starch digestion}

A first-order model has been used to describe the kinetics of starch hydrolysis [Goñi et al., 1997]. According to this equation, the percentage of starch hydrolyzed (C) at time $t$ (min), can be expressed as:

$$
\mathrm{C}=\mathrm{C}_{\infty}\left(1-\mathrm{e}^{-\mathrm{kt}}\right)
$$

where: $\mathrm{C}_{\infty}$ is the equilibrium percentage of starch hydrolyzed after $180 \mathrm{~min}$ and $\mathrm{k}(1 / \mathrm{min})$ is the kinetic constant. The percentage of starch hydrolyzed at time $t$ was determined following a procedure similar to that described for DS. The only difference was the enzymatic hydrolysis reaction time. In this case, samples were removed at 0, 30, 60, 90, 120, 150 and $180 \mathrm{~min}$. Each variety and each cooking condition were analyzed in triplicate. The kinetic parameters were determined by applying the experimental data to the model using the Microsoft Excel 2013 software. The hydrolysis index (HI) was calculated as the ratio of the area under the curve (AUC) for glucose hydrolysis of the samples 
and the AUC of a reference sample (white bread). The AUC was calculated using Eq. 2:

$$
\mathrm{AUC}=\mathrm{C}_{\infty}\left(\mathrm{t}_{\mathrm{f}}-\mathrm{t}_{0}\right)-\left(\mathrm{C}_{\infty} / \mathrm{k}\right)\left[1-\exp \left[-\mathrm{k}\left(\mathrm{t}_{\mathrm{f}}-\mathrm{t}_{0}\right)\right]\right]
$$

where: $t_{f}$ is the final time, $180 \mathrm{~min}$, and $t_{0}$ is the initial time (0 min). The hydrolysis index (HI) was used to estimate the glycemic index (EGI), using Eq. 3, described by Goñi et al. [1997]:

$$
\mathrm{EGI}=39.71+(0.549 \times \mathrm{HI})
$$

\section{Statistical analysis}

Statistical analyses were performed using XLSTAT 2014 software (Addinsoft, New York, USA). One-way analysis of variance (ANOVA) followed by Tukey's multiple range test for comparisons of means and least significant differences $(p<0.05)$ were performed with the data. All the data were expressed as the mean \pm standard deviation.

\section{RESULTS AND DISCUSSION}

\section{Texture and sensorial attributes}

The cooking times determined by the glass plate-white center method were 10 and 8 min for Basmati rice cooked at 95 and $100^{\circ} \mathrm{C}$, respectively. More extended cooking times were obtained for the Calrose, Arborio and Bomba varieties $\left(20 \mathrm{~min}\right.$ at $95^{\circ} \mathrm{C}$ and $15 \mathrm{~min}$ at $\left.100^{\circ} \mathrm{C}\right)$. These data are in agreement with the negative correlation found in other studies between cooking time and amylose content [Singh et al., 2005]. The moisture content of cooked rice of different varieties under different cooking conditions ranged from $61.9 \pm 0.5$ to $64.1 \pm 0.7 \mathrm{~g} / 100 \mathrm{~g}$; no trend was observed with the amylose content nor with the cooking conditions. Cooking times increased when the cooking water was kept at $95^{\circ} \mathrm{C}$ compared to the values obtained using boiling water. The differences in cooking times were more significant for Basmati rice than for the others. Figure 1 shows the results of the sensory evaluation of the Basmati and Arborio rice, this last considered as an example of the three Japonica varieties.

(a)

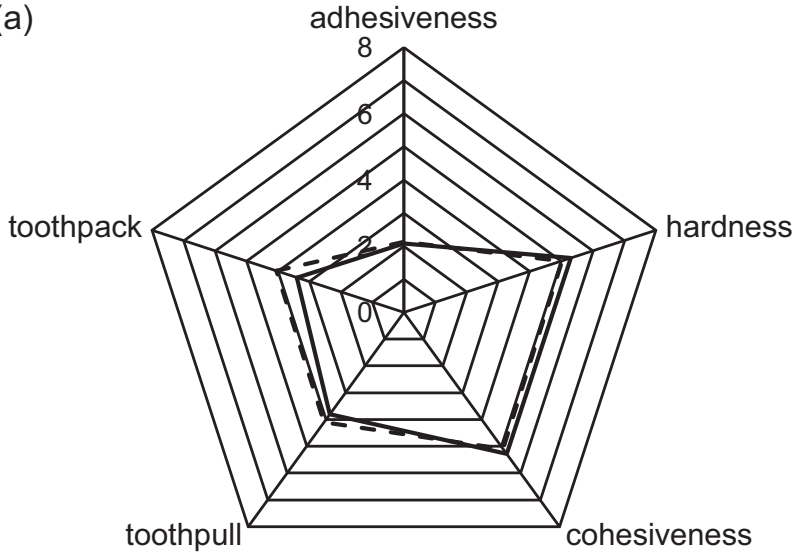

The profiles obtained for the Basmati and other varieties were very different. Basmati rice was described as harder, more cohesive, less adhesive, and with lower toothpull and toothpack values compared to the others. Numerous studies have found correlations between textural parameters of rice varieties and their amylose content [Mestres et al., 2011; Lu et al., 2013]. Varieties with a low amylose content, such as Calrose, Arborio and Bomba, are softer and have higher adhesiveness after cooking than varieties with a high amylose content, such as Basmati. The latter varieties are firmer, harder and less sticky.

The TPA results for the samples cooked under different conditions are shown in Table 1. The assessments of the sensory evaluation were verified by the TPA. The selected cooking times at 95 and $100^{\circ} \mathrm{C}$ were equivalent for the three textural parameters analyzed because no significant differences were observed between them $(\mathrm{P}>0.05)$. The same trend as in the sensory evaluation was observed; the variety with the higher amylose content (Basmati) had greater hardness and cohesiveness and lesser adhesiveness than the short-grain rice varieties (Calrose, Arborio and Bomba). Yu et al. [2009] studied the impact of amylose on rice texture and found a positive correlation between amylose content and hardness but a negative correlation with adhesiveness. They also obtained similar values for the textural parameters studied in varieties with a similar amylose content. Some authors have suggested that rice varieties with higher amylose contents are susceptible to this amylose leaching into the cooking medium, generating a coating film of retrograded amylose on the rice grains, increasing their hardness and reducing their stickiness [Leelayuthsoontorn \& Thipayarat, 2006]. Like hardness, cohesiveness seems to be related to amylose content; it is higher in the rice with a high amylose content [Singh et al., 2005]. Lu et al. [2013] corroborated this trend and obtained cohesiveness values within the range of those found in this study for varieties with similar amylose contents.

\section{Effect of cooking temperature and amylose content on resistant starch formation}

Table 2 shows the amylose, digestible starch (DS), resistant starch (RS) and total starch (TS) contents for four rice varieties at the selected cooking conditions. The TS values ranged from 84.1 to $85.9 \mathrm{~g} / 100 \mathrm{~g}$ on a dry matter basis.

(b)

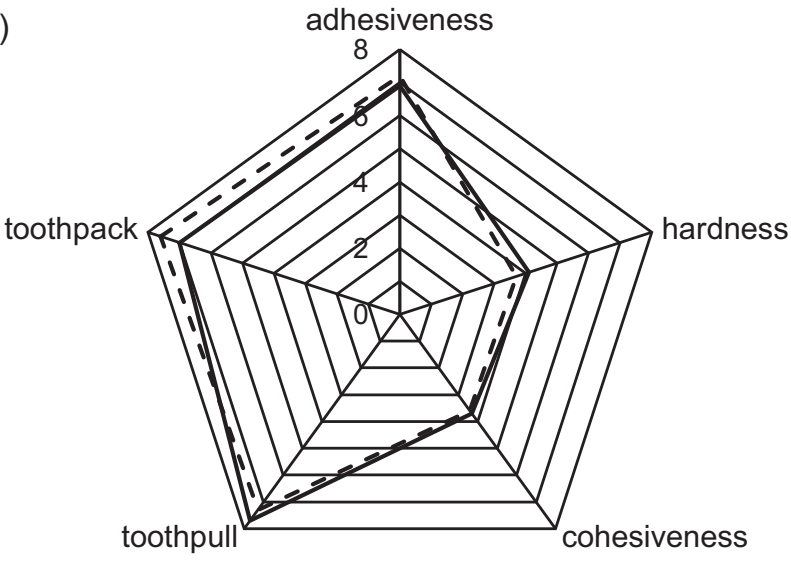

FIGURE 1. Sensory evaluation of samples cooked under different conditions. (a) Basmati: $100^{\circ} \mathrm{C}, 8$ min (dash line); $95^{\circ} \mathrm{C}, 10$ min (continuous line). (b) Arborio: $100^{\circ} \mathrm{C}, 15 \mathrm{~min}$ (dash line); $95^{\circ} \mathrm{C}, 20 \mathrm{~min}$ (continuous line). 
TABLE 1. Texture parameters of rice cultivars cooked at 95 and $100^{\circ} \mathrm{C}$.

\begin{tabular}{l|c|c|c|c}
\hline Cultivar & Cooking conditions & Hardness $(\mathrm{N})$ & Cohesiveness & Adhesiveness $(\mathrm{N} \times \mathrm{s})$ \\
\hline \multirow{2}{*}{ Basmati } & $95^{\circ} \mathrm{C} / 10 \mathrm{~min}$ & $65.03 \pm 3.31^{\mathrm{a}}$ & $0.58 \pm 0.04^{\mathrm{a}}$ & $2.29 \pm 0.23^{\mathrm{b}}$ \\
& $100^{\circ} \mathrm{C} / 8 \mathrm{~min}$ & $64.57 \pm 2.62^{\mathrm{a}}$ & $0.63 \pm 0.06^{\mathrm{a}}$ & $2.30 \pm 0.45^{\mathrm{b}}$ \\
Calrose & $95^{\circ} \mathrm{C} / 20 \mathrm{~min}$ & $52.36 \pm 3.85^{\mathrm{b}, \mathrm{A}}$ & $0.28 \pm 0.01^{\mathrm{b}, \mathrm{A}}$ & $5.86 \pm 0.47^{\mathrm{a}, \mathrm{A}}$ \\
& $100^{\circ} \mathrm{C} / 15 \mathrm{~min}$ & $53.24 \pm 3.85^{\mathrm{b}, \mathrm{A}}$ & $0.27 \pm 0.03^{\mathrm{b}, \mathrm{A}}$ & $5.45 \pm 0.55^{\mathrm{a}, \mathrm{A}}$ \\
\multirow{2}{*}{ Arborio } & $95^{\circ} \mathrm{C} / 20 \mathrm{~min}$ & $48.12 \pm 3.85^{\mathrm{b}, \mathrm{A}}$ & $0.20 \pm 0.02^{\mathrm{b}, \mathrm{BC}}$ & $6.60 \pm 0.58^{\mathrm{a}, \mathrm{A}}$ \\
& $100^{\circ} \mathrm{C} / 15 \mathrm{~min}$ & $47.70 \pm 4.31^{\mathrm{b}, \mathrm{A}}$ & $0.18 \pm 0.03^{\mathrm{b}, \mathrm{C}}$ & $6.63 \pm 0.67^{\mathrm{a}, \mathrm{A}}$ \\
Bomba & $95^{\circ} \mathrm{C} / 20 \mathrm{~min}$ & $47.36 \pm 1.54^{\mathrm{b}, \mathrm{A}}$ & $0.23 \pm 0.01^{\mathrm{b}, \mathrm{ABC}}$ & $6.56 \pm 0.68^{\mathrm{a}, \mathrm{A}}$ \\
& $100^{\circ} \mathrm{C} / 15 \mathrm{~min}$ & $48.23 \pm 2.89^{\mathrm{b}, \mathrm{A}}$ & $0.26 \pm 0.02^{\mathrm{b}, \mathrm{AB}}$ & $6.70 \pm 0.53^{\mathrm{a}, \mathrm{A}}$ \\
\hline
\end{tabular}

Values in the same column with different letters are significantly different at $\mathrm{P} \leq 0.05$. Lower case letters correspond to statistical analysis taking into account all the varieties and capital letters considering only Japonica varieties.

TABLE 2. Total starch (TS), resistant starch (RS), digestible starch (DS) and amylose content in raw and cooked rice expressed as percentage of dry matter (DM).

\begin{tabular}{|c|c|c|c|c|c|c|}
\hline \multirow{2}{*}{ Cultivar } & \multirow{2}{*}{ Cooking conditions } & \multirow{2}{*}{$\begin{array}{c}\text { TS } \\
(\mathrm{g} / 100 \mathrm{~g} \mathrm{DM})\end{array}$} & \multirow{2}{*}{$\begin{array}{c}\mathrm{RS} \\
(\mathrm{g} / 100 \mathrm{~g} \mathrm{DM})\end{array}$} & \multirow{2}{*}{$\begin{array}{c}\text { DS } \\
(\mathrm{g} / 100 \mathrm{~g} \mathrm{DM})\end{array}$} & \multicolumn{2}{|c|}{ Amylose } \\
\hline & & & & & $(\mathrm{g} / 100 \mathrm{~g} \mathrm{DM})$ & $(\mathrm{g} / 100 \mathrm{~g}$ TS $)$ \\
\hline Basmati & $\begin{array}{c}\text { Raw } \\
95^{\circ} \mathrm{C} / 10 \mathrm{~min} \\
100^{\circ} \mathrm{C} / 8 \mathrm{~min}\end{array}$ & $\begin{array}{l}85.3 \pm 0.3^{\mathrm{a}} \\
84.7 \pm 1.0^{\mathrm{a}} \\
85.3 \pm 0.5^{\mathrm{a}}\end{array}$ & $\begin{array}{c}11.2 \pm 1.2^{\mathrm{a}} \\
6.3 \pm 0.6^{\mathrm{c}} \\
4.3 \pm 0.4^{\mathrm{de}}\end{array}$ & $\begin{array}{l}74.1 \pm 0.6^{\mathrm{d}} \\
78.4 \pm 1.4^{\mathrm{bc}} \\
81.0 \pm 1.7^{\mathrm{ab}}\end{array}$ & $\begin{array}{l}22.2 \pm 1.0^{\mathrm{a}} \\
21.7 \pm 0.6^{\mathrm{a}} \\
21.6 \pm 0.6^{\mathrm{a}}\end{array}$ & $\begin{array}{l}26.0 \pm 1.0^{\mathrm{a}} \\
25.6 \pm 0.5^{\mathrm{a}} \\
25.3 \pm 0.3^{\mathrm{a}}\end{array}$ \\
\hline Calrose & $\begin{array}{c}\text { Raw } \\
95^{\circ} \mathrm{C} / 20 \text { min } \\
100^{\circ} \mathrm{C} / 15 \mathrm{~min}\end{array}$ & $\begin{array}{l}85.6 \pm 1.9^{\mathrm{a}, \mathrm{A}} \\
84.2 \pm 2.0^{\mathrm{a}, \mathrm{A}} \\
84.3 \pm 1.4^{\mathrm{a}, \mathrm{A}}\end{array}$ & $\begin{array}{l}7.8 \pm 0.6^{\mathrm{b}, \mathrm{A}} \\
5.3 \pm 0.4^{\mathrm{d}, \mathrm{B}} \\
2.3 \pm 1.3^{\mathrm{f}, \mathrm{C}}\end{array}$ & $\begin{array}{l}77.8 \pm 1.1^{\mathrm{bc}, \mathrm{CDE}} \\
78.9 \pm 1.4^{\mathrm{c}, \mathrm{BCD}} \\
82.0 \pm 0.7^{\mathrm{a}, \mathrm{A}}\end{array}$ & $\begin{array}{l}14.3 \pm 0.8^{\mathrm{b}, \mathrm{A}} \\
14.4 \pm 1.1^{\mathrm{b}, \mathrm{A}} \\
14.1 \pm 1.2^{\mathrm{b}, \mathrm{A}}\end{array}$ & $\begin{array}{l}16.7 \pm 0.5^{\mathrm{b}, \mathrm{A}} \\
17.1 \pm 0.2^{\mathrm{b}, \mathrm{A}} \\
16.7 \pm 1.0^{\mathrm{b}, \mathrm{A}}\end{array}$ \\
\hline Arborio & $\begin{array}{c}\text { Raw } \\
95^{\circ} \mathrm{C} / 20 \text { min } \\
100^{\circ} \mathrm{C} / 15 \mathrm{~min}\end{array}$ & $\begin{array}{l}84.7 \pm 1.3^{\mathrm{a}, \mathrm{A}} \\
85.9 \pm 1.8^{\mathrm{a}, \mathrm{A}} \\
85.5 \pm 1.9^{\mathrm{a}, \mathrm{A}}\end{array}$ & $\begin{array}{l}8.1 \pm 1.4^{\mathrm{b}, \mathrm{A}} \\
5.2 \pm 0.3^{\mathrm{d}, \mathrm{B}} \\
2.6 \pm 0.6^{\mathrm{f}, \mathrm{C}}\end{array}$ & $\begin{array}{l}76.6 \pm 0.2^{\mathrm{c}, \mathrm{E}} \\
80.7 \pm 0.9^{\mathrm{ab}, \mathrm{AB}} \\
82.9 \pm 1.1^{\mathrm{a}, \mathrm{A}}\end{array}$ & $\begin{array}{l}12.9 \pm 1.3^{\mathrm{bc}, \mathrm{AB}} \\
12.7 \pm 1.4^{\mathrm{bc}, \mathrm{AB}} \\
12.7 \pm 1.1^{\mathrm{bc}, \mathrm{AB}}\end{array}$ & $\begin{array}{l}15.2 \pm 1.2^{\mathrm{bc}, \mathrm{AB}} \\
14.8 \pm 1.3^{\mathrm{bc}, \mathrm{AB}} \\
14.8 \pm 1.0^{\mathrm{bc}, \mathrm{AB}}\end{array}$ \\
\hline Bomba & $\begin{array}{c}\text { Raw } \\
95^{\circ} \mathrm{C} / 20 \text { min } \\
100^{\circ} \mathrm{C} / 15 \text { min }\end{array}$ & $\begin{array}{l}84.8 \pm 0.7^{\mathrm{a}, \mathrm{A}} \\
84.1 \pm 1.6^{\mathrm{a}, \mathrm{A}} \\
85.1 \pm 0.8^{\mathrm{a}, \mathrm{A}}\end{array}$ & $\begin{array}{l}7.6 \pm 0.8^{\mathrm{b}, \mathrm{A}} \\
5.0 \pm 1.2^{\mathrm{d}, \mathrm{B}} \\
2.1 \pm 1.4^{\mathrm{f}, \mathrm{C}}\end{array}$ & $\begin{array}{l}77.2 \pm 0.8^{\mathrm{bc}, \mathrm{DE}} \\
79.1 \pm 1.4^{\mathrm{a}, \mathrm{ABC}} \\
83.0 \pm 1.9^{\mathrm{a}, \mathrm{A}}\end{array}$ & $\begin{array}{l}11.4 \pm 1.1^{\mathrm{c}, \mathrm{B}} \\
11.2 \pm 1.2^{\mathrm{c}, \mathrm{B}} \\
11.4 \pm 0.4^{\mathrm{c}, \mathrm{B}}\end{array}$ & $\begin{array}{l}13.4 \pm 0.5^{\mathrm{c}, \mathrm{C}} \\
13.3 \pm 0.7^{\mathrm{c}, \mathrm{C}} \\
13.3 \pm 0.8^{\mathrm{c}, \mathrm{C}}\end{array}$ \\
\hline
\end{tabular}

Values in the same column with different letters are significantly different at $\mathrm{P} \leq 0.05$. Lower case letters correspond to statistical analysis taking into account all the varieties and capital letters considering only Japonica varieties.

These values are in agreement with data reported in the literature [Yu et al., 2009]. A total of $26.0 \mathrm{~g} / 100 \mathrm{~g}$ of the total starch is amylose in the Basmati variety, but only $13.4 \mathrm{~g} / 100 \mathrm{~g}$ of the total starch is amylose in Bomba rice. In Arborio its represents $15.2 \mathrm{~g} / 100 \mathrm{~g}$ of amylose and $16.7 \mathrm{~g} / 100 \mathrm{~g}$ in Calrose rice. These values are similar to those found by Ahmed et al. [2015] and Chung et al. [2011]. The cooking process decreased the amount of amylose, probably due to its leaching into the water in both varieties, although this decrease was not significant. Sagum \& Arcot [2000] studied the amylose content after boiling and also found a decrease, but not statistically significant, in its content in most cases.

The RS content of raw rice was high in the analyzed varieties (11.2, 7.8, 8.1 and 7.6 g/100 g DM for Basmati, Calrose, Arborio and Bomba rice, respectively). This can be attributed to the nature of the starch present in unprocessed and uncooked raw kernels (RS type 1), which is of the B-type crystal structure and highly resistant to $\alpha$-amylase [Sagum \& Arcot, 2000; Han et al., 2008]. After cooking, the RS levels were significantly reduced. The RS content in the Basmati variety was reduced less than in the rest of the short-grain varieties when samples cooked at the same temperature were compared. These results agreed with those reported in the literature $[\mathrm{Hu}$ et al., 2004]. A higher amylose content caused a decrease in starch digestibility because it reduces the susceptibility of starch to enzymatic hydrolysis, leading to an increase in the formation of resistant starch. Furthermore, Chung et al. [2011] showed that the starch from long-grain rice with a high amylose content had a significantly higher gelatinization temperature. A reduction in the content of resistant starch after cooking was observed in both varieties. The cooking temperature had a significant influence on the resistant starch content. At $100^{\circ} \mathrm{C}$, the RS content was significantly lower than that at $95^{\circ} \mathrm{C}$ for both varieties. According to Sagum \& Arcot [2000], resistant starch in raw products could be attributed to the crystalline structure of starch. Resistant starch after cooking (resistant starch type III) could be formed in part due to the retrogradation of amylose. During cooking, the starch granule loses its native structure because of the effect of temperature and water absorption. In addition, when rice cools, new links between amylose molecules form a rigid gel resistant to digestive enzymes.

\section{Effect of cooking temperature on hydrolysis index and estimated glycemic index}

Table 3 shows the in vitro starch digestion results, including: the estimated parameters, $\mathrm{C} \infty$ and $\mathrm{k}$, from the starch hydrolysis kinetics; the hydrolysis index (HI); and the estimated glycemic index (EGI). The starch hydrolysis curves for raw and cooked samples are shown in Figure 2. The extent of starch hydrolysis depended significantly on the variety and the cooking temperature. It seems that a reduc- 
TABLE 3. Kinetic parameters $\left(\mathrm{C}_{\infty}\right.$ and $\left.\mathrm{k}\right)$, hydrolysis index $(\mathrm{HI})$ and estimated glycemic index (EGI) of raw and cooked rice.

\begin{tabular}{|c|c|c|c|c|c|c|}
\hline Cultivar & Cooking conditions & $\begin{array}{c}\text { Amylose } \\
\text { (g/100 g DM) }\end{array}$ & $\mathrm{C}_{\infty}$ & $\mathrm{k}[1 / \mathrm{min}]$ & $\mathrm{HI}$ & EGI \\
\hline Basmati & $\begin{array}{c}\text { Raw } \\
95^{\circ} \mathrm{C} / 10 \text { min } \\
100^{\circ} \mathrm{C} / 8 \text { min }\end{array}$ & $\begin{array}{l}22.2 \pm 1.0^{\mathrm{a}} \\
21.7 \pm 0.6^{\mathrm{a}} \\
21.6 \pm 0.6^{\mathrm{a}}\end{array}$ & $\begin{array}{r}4.4 \pm 0.4^{\mathrm{g}} \\
52.2 \pm 2.3^{\mathrm{e}} \\
59.3 \pm 1.5^{\mathrm{d}}\end{array}$ & $\begin{array}{l}0.011 \pm 0.002^{\mathrm{f}} \\
0.013 \pm 0.001^{\mathrm{f}} \\
0.017 \pm 0.001^{\mathrm{e}}\end{array}$ & $\begin{array}{r}3.9 \pm 0.4^{\mathrm{h}} \\
49.8 \pm 2.4^{\mathrm{f}} \\
63.5 \pm 1.8^{\mathrm{e}}\end{array}$ & $\begin{array}{l}41.9 \pm 0.3^{\mathrm{f}} \\
67.0 \pm 2.1^{\mathrm{d}} \\
74.6 \pm 2.4^{\mathrm{c}}\end{array}$ \\
\hline Calrose & $\begin{array}{c}\text { Raw } \\
95^{\circ} \mathrm{C} / 20 \mathrm{~min} \\
100^{\circ} \mathrm{C} / 15 \mathrm{~min}\end{array}$ & $\begin{array}{l}14.3 \pm 0.8^{\mathrm{b}, \mathrm{A}} \\
14.4 \pm 1.1^{\mathrm{b}, \mathrm{A}} \\
14.1 \pm 1.2^{\mathrm{b}, \mathrm{A}}\end{array}$ & $\begin{array}{c}7.0 \pm 0.6^{\mathrm{f}, \mathrm{E}} \\
60.1 \pm 2.0^{\mathrm{d}, \mathrm{D}} \\
67.3 \pm 1.8^{\mathrm{b}, \mathrm{B}}\end{array}$ & $\begin{array}{l}0.011 \pm 0.001^{\mathrm{f}, \mathrm{D}} \\
0.016 \pm 0.001^{\mathrm{e}, \mathrm{C}} \\
0.022 \pm 0.002^{\mathrm{c}, \mathrm{B}}\end{array}$ & $\begin{array}{r}6.1 \pm 0.7^{\mathrm{g}, \mathrm{F}} \\
62.8 \pm 2.1^{\mathrm{e}, \mathrm{E}} \\
78.7 \pm 2.4^{\mathrm{c}, \mathrm{C}}\end{array}$ & $\begin{array}{l}43.0 \pm 0.5^{\mathrm{e}, \mathrm{F}} \\
74.2 \pm 2.0^{\mathrm{c}, \mathrm{E}} \\
82.9 \pm 2.3^{\mathrm{b}, \mathrm{C}}\end{array}$ \\
\hline Arborio & $\begin{array}{c}\text { Raw } \\
95^{\circ} \mathrm{C} / 20 \mathrm{~min} \\
100^{\circ} \mathrm{C} / 15 \mathrm{~min}\end{array}$ & $\begin{array}{l}12.9 \pm 1.3^{\mathrm{bc}, \mathrm{AB}} \\
12.7 \pm 1.4^{\mathrm{bc}, \mathrm{AB}} \\
12.7 \pm 1.1^{\mathrm{bc}, \mathrm{AB}}\end{array}$ & $\begin{array}{c}7.4 \pm 0.6^{\mathrm{f}, \mathrm{E}} \\
65.5 \pm 1.9^{\mathrm{c}, \mathrm{C}} \\
71.0 \pm 2.8^{\mathrm{ab}, \mathrm{AB}}\end{array}$ & $\begin{array}{l}0.011 \pm 0.001^{\mathrm{f}, \mathrm{D}} \\
0.017 \pm 0.001^{\mathrm{e}, \mathrm{C}} \\
0.026 \pm 0.001^{\mathrm{b}, \mathrm{A}}\end{array}$ & $\begin{array}{r}6.5 \pm 0.8^{\mathrm{g}, \mathrm{F}} \\
70.1 \pm 2.3^{\mathrm{d}, \mathrm{D}} \\
87.0 \pm 2.5^{\mathrm{b}, \mathrm{B}}\end{array}$ & $\begin{array}{l}43.3 \pm 0.4^{\mathrm{e}, \mathrm{F}} \\
78.2 \pm 1.7^{\mathrm{b}, \mathrm{D}} \\
87.5 \pm 3.0^{\mathrm{a}, \mathrm{B}}\end{array}$ \\
\hline Bomba & $\begin{array}{c}\text { Raw } \\
95^{\circ} \mathrm{C} / 20 \text { min } \\
100^{\circ} \mathrm{C} / 15 \mathrm{~min}\end{array}$ & $\begin{array}{l}11.4 \pm 1.1^{\mathrm{c}, \mathrm{B}} \\
11.2 \pm 1.2^{\mathrm{c}, \mathrm{B}} \\
11.4 \pm 0.4^{\mathrm{c}, \mathrm{B}}\end{array}$ & $\begin{array}{r}7.8 \pm 0.7^{\mathrm{f,E}} \\
66.7 \pm 2.2^{\mathrm{c}, \mathrm{C}} \\
75.1 \pm 2.0^{\mathrm{a}, \mathrm{A}}\end{array}$ & $\begin{array}{l}0.012 \pm 0.002^{\mathrm{f}, \mathrm{D}} \\
0.019 \pm 0.001^{\mathrm{d}, \mathrm{BC}} \\
0.029 \pm 0.001^{\mathrm{a}, \mathrm{A}}\end{array}$ & $\begin{array}{c}7.2 \pm 0.8^{\mathrm{g}, \mathrm{F}} \\
74.4 \pm 2.3^{\mathrm{cd}, \mathrm{CD}} \\
94.5 \pm 2.1^{\mathrm{a}, \mathrm{A}}\end{array}$ & $\begin{array}{l}43.7 \pm 0.5^{\mathrm{e}, \mathrm{F}} \\
80.5 \pm 2.2^{\mathrm{b}, \mathrm{CD}} \\
91.6 \pm 2.2^{\mathrm{a}, \mathrm{A}}\end{array}$ \\
\hline
\end{tabular}

Values in the same column with different letters are significantly different at $\mathrm{P} \leq 0.05$. Lower case letters correspond to statistical analysis taking into account all the varieties and capital letters considering only Japonica varieties.

tion in cooking temperature produced a lower hydrolysis in the four rice varieties studied. Pronounced differences between cooking temperatures and rice varieties could also be observed in terms of starch digestibility and glycemic response.

For both cooking conditions, the short-grain varieties (Calrose, Arborio and Bomba) showed a higher estimated glycemic index than Basmati, probably due to its lower amylose content. Starch digestibility and the glycemic response are related to amylose content, as has been described in previous studies, both in vitro [Hu et al., 2004] and in vivo [Srikaeo \& Sangkhiaw, 2014]. The digestibility of starch in rice may also be affected by the fine structural features of both amylose and amylopectin and by non-starch components, such as protein and cell-wall matrices which can entrap starch granules, and lipids which form complexes with amylose [Syahariza et al., 2013]. These factors could explain the differences between the in vitro starch hydrolysis trends of the three Japonica cultivars.

The degree of cooking had a also significant influence on the glycemic response. Cooking time determines the extent of starch gelatinization and, as a consequence, the digestibility of rice [Ranawana et al., 2009; Al-Mssallem et al., 2011]. The swelling and gelatinization of starch granules during cooking exert pressure on the grain center affecting the microstructure. After cooking, the peripheral cells remain intact while the central endosperm displays hollows [Lu et al., 2013]. The high amylose content of such varieties as Basmati results in a strong physical structure, with few hollows, which hinders the disruption of the central part of the grain, and consequently this variety after cooking is harder compared with the short grain varieties (Calrose, Arborio and Bomba). During hydrolysis, $\alpha$-amylase disrupted the structure near the hollow cavities resulting

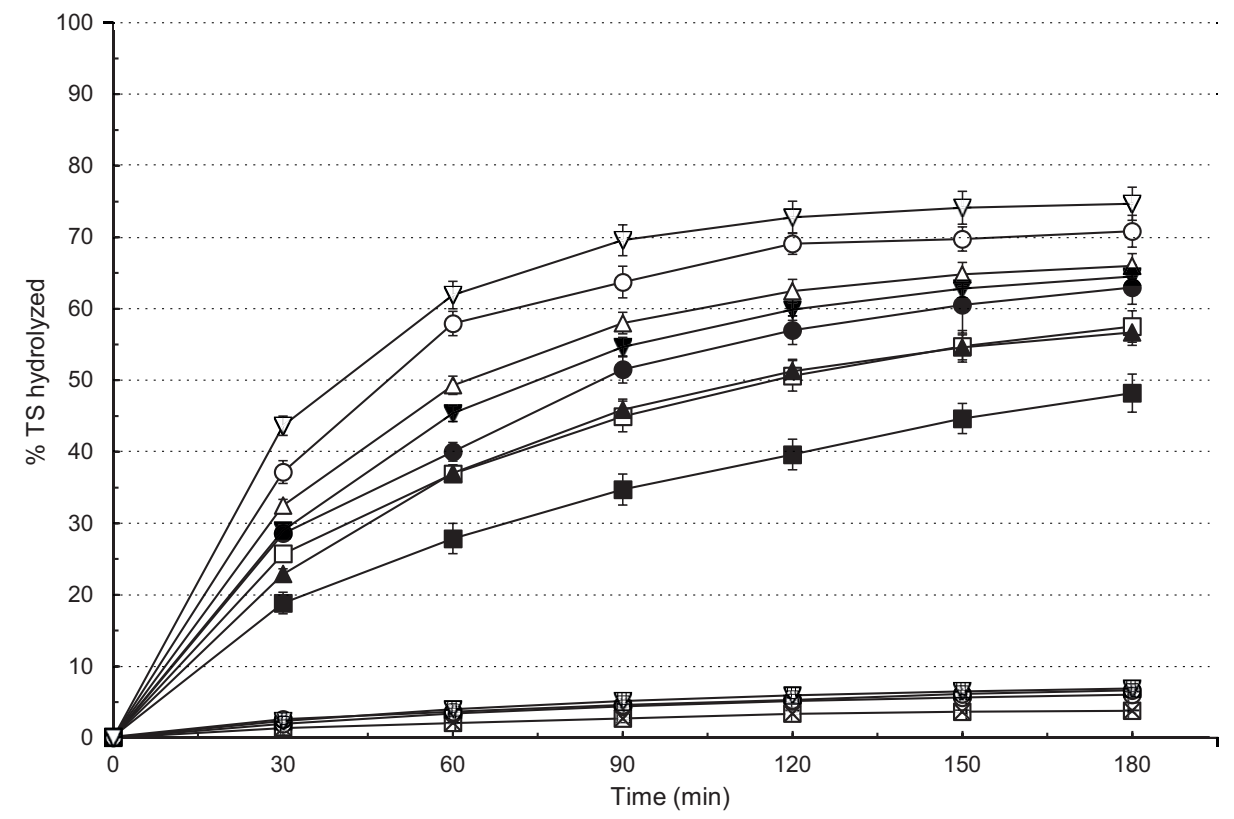

FIGURE 2. In vitro total starch (TS) hydrolysis curves of Basmati (squares), Calrose (up-triangles), Arborio (circles) and Bomba (down-triangles) rice. Raw: crossways symbols, cooked at $95^{\circ} \mathrm{C}$ : full symbols and cooked at $100^{\circ} \mathrm{C}$ : hallow symbols. 
in a quicker hydrolysis rate in the grains with more voids, giving a higher estimated glycemic index.

Cooking at a temperature lower than $100^{\circ} \mathrm{C}$ implies an increase in the cooking time to obtain a product with a similar degree of cooking. Taking into account that samples cooked at 95 and $100^{\circ} \mathrm{C}$ did not show significant differences in terms of sensory or instrumental texture profile analysis (Figure 1 and Table 1), it is especially relevant that rice cooked at $95^{\circ} \mathrm{C}$ has a lower estimated glycemic index than rice cooked at $100^{\circ} \mathrm{C}$, although the cooking time is greater than during the cooking in boiling water. Tamura et al. [2016] evaluated the effect of the degree of cooking on starch hydrolysis and concluded that the hydrolysis index and the estimated glycemic index increase with the level of cooking. Nevertheless, in our case, the factor that affected starch digestibility more acutely was not the level of cooking but the cooking temperature. Cooking rice at $95^{\circ} \mathrm{C}$ instead of $100^{\circ} \mathrm{C}$ reduced the glycemic index, probably because a decrease in the cooking temperature produces an incomplete gelatinization and retrogradation of the starch, and consequently, leads to the formation of more resistant.

\section{CONCLUSIONS}

We compared four rice varieties cooked at equivalent temperature and time conditions using sensory and instrumental texture analyses. The results show that the resistant starch content of cooked rice depended on both the cooking conditions and the initial amylose content. Raw Basmati rice had a higher amylose and resistant starch contents than raw Arborio, Calrose and Bomba which had similar RS contents. After cooking, amylose levels were maintained for all varieties studied; however, the resistant starch content decreased in all cases. Rice cooked at $95^{\circ} \mathrm{C}$ had a higher content of resistant starch than rice cooked at $100^{\circ} \mathrm{C}$ in all varieties studied, showing differences in the digestibility kinetics of samples cooked at the different temperatures. The results obtained from the in vitro study showed that starch hydrolysis tended to be faster and more complete for rice with a lower amylose content and for rice cooked at $100^{\circ} \mathrm{C}$ compared to that cooked at $95^{\circ} \mathrm{C}$. For those people who need to control the glycemic index, it would be advisable to cook rice at $95^{\circ} \mathrm{C}$ without unduly prolonging the cooking time. This would result in rice with organoleptic properties similar to that of rice cooked in boiling water while achieving a reduction in the glycemic index of approximately $10 \%$.

\section{RESEARCH FUNDING}

The project "Application of culinary technology for the improvement and development of automatic systems for controlling temperature" (2012/0138) was financially supported by BSH Electrodomésticos España, S.A.

\section{REFERENCES}

1. AACC Approved Methods. 2000. American Association of Cereal Chemistry, 10th ed., St. Paul, Minnesota.

2. Ahmed N., Tetlow I.J., Nawaz S., Iqbal A., Mubin M., Rehman M.S.N., Butt A., Lightfoot D.A., Maekawa M., Effect of high temperature on grain filling period, yield, amylose content and activity of starch Biosynthesis enzymes in endosperm of basmati rice. J. Sci. Food Agric., 2015, 95, 2237-2243.

3. Al-Mssallem M.Q., Hampton S.M., Frost G.S., Brown J.E., A study of Hassawi rice (Oryza sativa L.) in terms of its carbohydrate hydrolysis (in vitro) and glycaemic and insulinaemic indices (in vivo). Eur. J. Clin. Nutr., 2011, 65, 627-634.

4. AOAC Official Methods of Analysis. 1990. Association of Official Analytical Chemists, 15th ed.,Washington, DC.

5. Champ M., Langkilde A.M., Brouns F., Kettlitz B., Le Bail-Collet Y., Advances in dietary fibre characterisation. 2. Consumption, chemistry, physiology and measurement of resistant starch; implications for health and food labelling. Nutr. Res. Rev., 2003, 16, 143-161.

6. Chung H., Liu Q., Lee L., Wei D., Relationship between the structure, physicochemical properties and in vitro digestibility of rice starches with different amylose contents. Food Hydrocolloid., 2011, 25, 968-975.

7. Goñi I., García-Alonso A., Saura-Calixto F., A starch hydrolysis procedure to estimate glycemic index. Nutr. Res., 1997, 17, 427-437.

8. Han S.H., Lee S.W., Rhee C., Effect of cooking methods on starch hydrolysis kinetics and digestion resistant fractions of rice and soybean. Eur. Food Res. Technol., 2008, 227, 1315-1321.

9. Hu P.S., Zhao H.J., Duan Z.Y., Zhang L.L., Wu D.X., Starch digestibility and the estimated glycemic score of different types of rice differing in amylose contents. J. Cereal Sci., 2004, 40, 231-237.

10. Kaur B., Ranawana V., Henry J., The glycemic index of rice and rice products: A review, and table of GI values. Crit. Rev. Food Sci. Nutr., 2016, 56, 215-236.

11. Leelayuthsoontorn P., Thipayarat A., Textural and morphological changes of Jasmine rice under various elevated cooking conditions. Food Chem., 2006, 96, 606-613.

12. Li H., Prakash S., Nicholson T.M., Fitzgerald M.A., Gilbert R.G., The importance of amylose and amylopectin fine structure for textural properties of cooked rice grains. Food Chem., 2016, 196, 702-711.

13. Lu S., Cik T., Lii C., Lai P., Chen H., Effect of amylose content on structure, texture and $\alpha$-amylase reactivity of cooked rice. LWT-Food Sci. Technol., 2013, 54, 224-228.

14. Meilgaard M., Civille G.V., Carr B.T., Sensory evaluation techniques. 2006, CRC Press Inc., Boca Raton, Florida.

15. Mestres C., Ribeyre F., Pons B., Fallet V., Matencio F., Sensory texture of cooked rice is rather linked to chemical than to physical characteristics of raw grain. J. Cereal Sci., 2011, 53, 81- 89.

16. Meullenet J.F.C., Gross J., Marks B.P., Daniels M., Sensory descriptive texture analyses of cooked rice and its correlation to instrumental parameters using an extrusion cell. Cereal Chem., 1998, 75, 714-720.

17. Miao W., Wang L., Xu X., Pan S., Evaluation of cooked rice texture using a novel sampling technique. Measurement, 2016, 89, 21-27.

18. Ranawana D.V., Henry C.J.K., Lightowler H.J., Wang D., Glycaemic index of some commercially available rice and rice products in Great Britain. Int. J. Food Sci. Nutr., 2009, 60, 99-110.

19. Reed M.O., Ai Y., Leutcher J.L., Jane J.L., Effects of cooking methods and starch structures on starch hydrolysis rates of rice. J. Food Sci., 2013, 78, H1076-H1081. 
20. Sagum R., Arcot J., Effect of domestic processing methods on the starch, non-starch polysaccharides and in vitro starch and protein digestibility of three varieties of rice with varying levels of amylose. Food Chem., 2000, 70, 107-111.

21. Singh N., Kaur L., Sodhi N.S., Sekhon K.S., Physicochemical, cooking and textural properties of milled rice from different Indian rice cultivars. Food Chem., 2005, 89, 253-259.

22. Srikaeo K., Sangkhiaw J., Effects of amylose and resistant starch on glycaemic index of rice noodles. LWT-Food Sci. Technol. 2014, 59, 1129-1135.

23. Syahariza Z.A., Sar S., Hasjim J., Tizzotti, M.J., Gilbert, R.G., The importance of amylose and amylopectin fine structures for starch digestibility in cooked rice grains. Food Chem., 2013, 136, 742-749.

24. Tamura M., Singh J., Kaur L., Ogawa Y., Impact of the degree of cooking on starch digestibility of rice - An in vitro study. Food Chem., 2016, 191, 98-104.

25. Trinidad T.P., Mallillin A.C., Encabo R.R., Sagum R.S., Felix A.D.R., Juliano B.O., The effect of apparent amylose content and dietary fibre on the glycemic response of different varieties of cooked milled and brown rice. Int. J. Food Sci. Nutr., 2013, 64, 89-93.
26. Varavinit S., Shobsngob S., Varanyanond W., Chinachoti P., Naivikul O., Effect of amylose content on gelatinization, retrogradation and pasting properties of flours from different cultivars of Thai rice. Starch-Stärke, 2003, 55, 410-415.

27. Yu S., Ma Y., Sun D-W., Impact of amylose content on starch retrogradation and texture of cooked milled rice during storage. J. Cereal Sci., 2009, 50, 139-144.

28. Yun S.H., Matheson N.K., Estimation of amylose content of starches after precipitation of amylopectin by concanavalinA. Starch-Stärke, 1990, 42, 302-305.

29. Zhang X., Wang L., Cheng M., Wang R., Luo X., Li Y., Chen Z., Influence of ultrasonic enzyme treatment on the cooking and eating quality of brown rice. J. Cereal Sci., 2015, 63, 140-146.

30. Zhu L.J., Liu Q.Q., Wilson J.D., Gua M.H., Shi Y.C., Digestibility and physicochemical properties of rice (Oryza sativa L.) flours and starches differing in amylose content. Carbohydr. Polym., 2011, 86, 1751-1759.

Submitted: 17 July 2017. Revised: 22 January 2018. Accepted: 7 March 2018. Published on-line: 28 March 2018. 